\title{
Spatial Distribution of Strategic Crops by Administrative Units in Anbar Governorate for The Year 2018
}

\author{
Amna Jabbar Matar Darwish Al-Dulaimi, Jameela Nafeh Sabbar Al-Hiti* \\ College of Literature, Anbar University, Iraq \\ *alhytyalshmry@gmail.com
}

\begin{abstract}
:
The strategic crops in Anbar are represented by wheat, yellow corn, and barley, as the total area of them reached (314763) denims, of which (211984) denims of wheat, (66997) denims of corn, and (35755) denims of barley, and for the various administrative units of the governorate, Also, with different production quantities amounted to (204918) tons for wheat, (33497) tons for yellow corn, and (10725) tons for barley, achieving a significant moral difference when applying the Kay square to the cultivated areas and production quantities, as the standard value of wheat crop reached $(147,376)$ The cultivated area, and $(144,330)$ of the production amount. As for the standard value of the maize crop, it reached $(43,100)$ for the area, and $(82,119)$ for production, as for the barley crop, the standard value for the cultivated area was $(77,465)$ and $(128,604)$ for the amount of production, the moral difference between the cultivated area and the amount of production for all strategic crops cultivated in the governorate reached (0.01), representing a significant moral difference between them.
\end{abstract}

Keywords: $\quad$ Production; Strategic Crops; Wheat; Corn; Barley; Value.

Crossref doi https://doi.org/10.51345/.v32i1.197.g200 


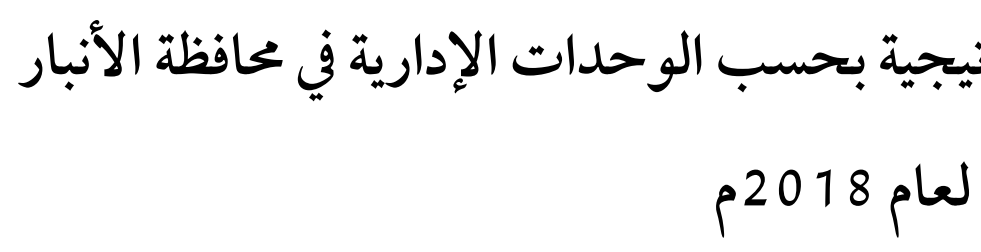 \\ أ.م.د آمنة جبار مطر درويث الدليمي، جميلة نافع صبار الميتي" \\ كلية الآداب، جامعة الأنبار، العراق \\ * alhytyalshmry@gmail.com}

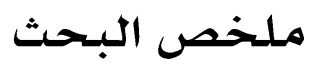

تتمثل المحاصيل الاستراتيجية في محافظة الانبار بـ(القمح والذرة الصفراء والشعير)، اذ بلغت المساحة الكلية لها (314763) دونم، منها (211984) دونم للقمح، و(66997) دونم للذرة، و(35755) دونم للشعير، ولمختلف الوحدات الادارية للمحافظة، وبكميات انتاج متباينة ايضاً بلغت (204918) طن للقمح، و(33497) طن للذرة الصفراء، و(10725) طن للشعير، محققة بذلك فرقاً معنوياً كبيراً عند تطبيق (مربع كاي) على المساحات المزروعة وكميات الانتاج، اذ بلغت القيمة المعيارية لمحصول القمح $(147,376)$ للمساحة المزروعة، و(144,330) لكمية الانتاج، اما القيمة المعيارية لمحصول الذرة الصفراء فبلغ (43,100) للمساحة، و(82,119) للإنتاج، اما محصول الشعير فبلغت القيمة المعيارية للمساحة المزروعة (77,465)، و(128,604) لكمية الانتاج، ليصل الفرق المعنوي بين المساحة المزروعة وكمية الانتاج لجميع المحاصيل الاستراتيجية المزروعة في المحافظة المى (0,01)، مثثلاً بذلك فرقاً معنوياً كبيراً بينها. 
المقدمة :

تعد محاصيل الحبوب من النباتات النجيلية (Phocaea) الاقتصادية التي تزرع لغرض تهيئة الغذاء للانسان، وهي مصدراً غذائياً رئيساً لمعظم الشعوب فضلاً عن كونها مصدراً لكثير من الصناعات الغذائية الضرورية(1). كما يستخدم جزء منها علفاً للحيوانات اما بصورة رئيسية عن طريق منتجاتها او غير رئيسة عن طريق سيقانها او مخلفات عمليات الحصاد وطحن الحبوب(2). فضلاً عن سهولة زراعتها والعناية بها لانها تزرع بمساحات واسعة مما يسهل الاعتماد على المكننة كلياً في زراعتها، فلا يعتمد على الكثير من الايدي العاملة، كما يسهل خزن انتاجها من الحبوب(3). وتحتوي الحبوب على (83\%) كربوهيدرات وتتراوح نسبة البروتين فيها بين (5،6 - 18\%) اما محتواها من الدهون فيتراوح بين (1-5\%) وتشكل مصدراً رئيسياً للطاقة

(السعرات الحرارية)، والمعادن و الكالسيوم، فضلاً عن كونها غنية بالفيتامينات ولاسيا بجموعة فيتامين (B). وان جميع محاصيل الحبوب (Cereal Crops) حولية (Annul Crops)، اي انها تكمل دورتها في موسم واحد ومعظمها اما شتوية او ربيعية، وان القمح يأخذ المرتبة الاولى من بين المحاصيل الاستراتيجية الاساسية، لاحتوائه على قدر كبير من البروتينات والسعرات الحرارية، يليها الذرة الصفراء والشعير ذات الاهمية الزراعية في المحافظة، ومن اجل اعطاء صورة واقعية ودقيقة لواقع انتاج المحاصيل الاستراتيجية في منطقة الدراسة ومن اجل التوصل الى تحليل علمي صحيح لكميات انتاجها ، فمن الضروري على الباحث الجغر افي ان يعتمد على الدقة في التحليل والتي لا يمكن تحققها الا عن طريق وحدة قياس يعتمدها لغرض تحقيق الهدف الذي يسعى إليه.

\section{مشكلة البحثث:}

كيف اسهمت الظروف الطبيعية والبشرية في انخفاض انتاجية محاصيل الحبوب الاستراتيجية (القمح، الذرة الصفراء، الشعير)، وكذلك الحاجة الى توفير الغذاء للسكان. 


\section{فرضيـة البـحث:}

الظروف الطبيعية والبشرية اسهمت في انخفاض انتاجية محاصيل الحبوب الاستراتيجية (القمح، الذرة الصفراء و الشعير). (2) (1)

\section{هـف البـحث:}

تأتي اهمية وهدف البحث من خلال الاهتمام بمعرفة مساحة المحافظة وامكانيتها للإنتاج الغذائي الاستراتيجي المتمثل بـ(القمح، الذرة الصفراء، الشعير)، والاساس لتغذية السكان، ودراسة واقع انتاج المحاصيل الاستراتيجية في المحافظة .

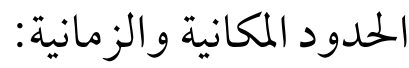
شملت الدراسة كافة الاراضي الزراعية في محافظة الانبار الواقعة بين دائرتي عرض (31.15- 35) شهالاً وبين خطي طول (39-- 43.30) شرقاً، والمزروعة بمحاصيل الحبوب الاستراتيجية (القمح، الذرة الصفراء، الشعير) )، وذلك خلال عام 2018 .

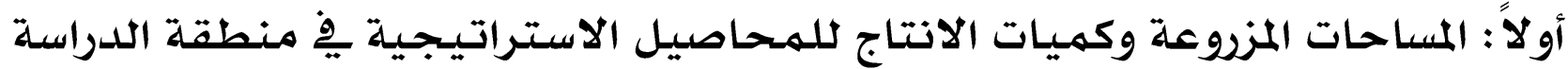
اعتمد الجغر افيون على وحدة المساحة وكمية الانتاج في دراسة وتحليل الانتاج الزراعي، وتقع منطقة الدراسة في الجزء الغربي من العراق وتبلغ المساحة الكلية للمحافظة (5512300) دونمً وبنسبة (3/1) مساحة العراق ان المساحة المزروعة لعام 180 م بلغت (483764) دونم، والمساحة المزروعة بمحاصيل الحبوب بلغت (314763) دونمً، اي بنسبة (65\%) من المساحة الكلية المزروعة للمدة المذكورة. وهذا يعد مؤشراً جيد نحو استثمار الار اضي الصالحة للزراعة وتنميتها نتيجة التوجه المدروس و المخطط والدعم الحكومي. يتضح من الجلدول (1 ) والذي يبين المساحة الكلية المزروعة للمحافظة ومساحة المزروع بالحبوب ونسبتها من المزروعة اذ بلغت المساحة الكلية المزروعة للمحافظة (483764) دونم اذ استغل منها (314736) دونم لزراعة

$$
\text { الحبوب الاستراتيجية وبنسبة (65\%) منها . }
$$


فمن حيث المساحات الكلية المزروعة اوضح الجمدول ان المرتبة الاولى كانت لقضاء الفلوجة بـ(275093) دونم وبنسبة (56,9\%) يليه قضاء الرمادي بالمرتبة الثانية بمساحة بلغت (95058) دونم وبنسبة (19,6\%) في حين تصدر قضاء عنه المرتبة الثالثة بـ(43535) دونم ونسبتها (9\%) ليأتي بعدها وبالمرتبة الرابعة قضاء القائم بـ(27301) دونم وبنسبة (5,6\%) وبالمرتبة الخامسة قضاء هيت بمساحة (26254) دونم وبنسبة (5,4\%)، اما اقضية حديثة والرطبة وراوه جاءت ضمن المرتبة السادسة والسابعة والثامنة وبالمساحات (6187)، (6000)، (4336)

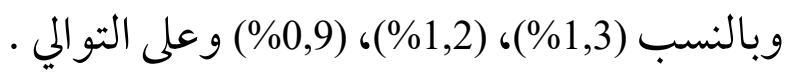
اما مساحة ما مزروع من الحبوب ونسبها من المساحة الكلية المزروعة فهي ايضا متباينة من قضاء لآخر فتصدر المرتبة الاولى قضاء الفلوجة بمساحة (165552) دونم وبنسبة (34,3\%) من المساحة الكلية، وبالمرتبة الثانية جاء قضاء الرمادي بـ(89608) دونم وبنسبة (18,5\%) وبعده قضائي القائم وعنه بالمرتبة الثالثة و الر ابعة وبمساحات ونسب هي (23111) دونم و( 16285) دونم و(4،7\%).

جدول (1 ) : التوزيع الجغرافي و النسبي للمساحة المزروعة والمساحة المزروعة بالمحاصيل الاستراتيجية في منطقة الدراسة لعام 2018

\begin{tabular}{|c|c|c|c|c|c|}
\hline $\begin{array}{c}\text { المساحة الكلية من } \\
\text { \% }\end{array}$ & $\%$ & مساحة محاصيل الحبوب & $\%$ & المساحة المزروعة / دونم & القضاء \\
\hline 18,5 & 28,5 & 89608 & 19,6 & 95058 & الرمادي \\
\hline 34,3 & 52,6 & 165552 & 56,9 & 275093 & الفلوجة \\
\hline 2 & 3,2 & 10031 & 5,4 & 26254 & هيت \\
\hline 1 & 1,5 & 4668 & 1,3 & 6187 & حديثة \\
\hline 3,3 & 5,2 & 16285 & 9 & 43535 & عنه \\
\hline 1,2 & 1,7 & 5481 & 0,9 & 4336 & راوه \\
\hline 4,7 & 3,7 & 23111 & 5,6 & 27301 & القائم \\
\hline- & - & - & 1,2 & 6000 & الرطبة \\
\hline$\% 65$ & 100 & 314763 & 100 & 483764 & الجموع \\
\hline
\end{tabular}

المصدر: وزارة الزراعة، مديرية زراعة محافظة الانبار، قسم التخطيط، بيانات غير منشورة، 2018 م. 
و(3،3\%) وبالترتيب ولتبقى ضمن المراتب الخامسة والسادسة والسابعة كل من الاقضية (هيت، راوه، حديثة) وبالمساحات (10031، 6000، 5481، 4668) دونما على التوالي ويالنسب (2\%، 1.2\%، 1\%) وعلى التوالي ايضا، ليخرج قضاء الرطبة من التسلسل المساحي والنسبي لعدم توفر البيانات الخاصة به لهذا العام، وكما نجد في الجدول نفسه اختلاف المر اتب النسبية بين المساحات المزروعة بالحبوب بين الاقضية نفسها. يتضح من الجمدول (2) نسبة المساحات المزروعة بالمحاصيل الاستراتيجية من المساحة الكلية المزروعة (دونم) لمنطقة الدراسة لعام 180 م، وقد تباينت نسب المساحات المزروعة بالمحاصيل بين الوحدات، اذ بلغت بموع المساحات الكلية المزروعة للمحافظة (483764) دونمً، وبلغت المساحات المزروعة بالقمح (211984) دونم، اما نسبة المساحة المزروعة بالقمح من المساحة الكلية المزروعة اذ تبو أ المرتبة الاولى قضاء الفلوجة بنسبة (43,8\%) من المساحة الكلية المزروعة، بينها تصدر المرتبة الثانية والثالثة قضائي الرمادي والقائم بنسبة (12,5\%) و(2,1\%) على التتابع، بينما تمثلت المراتب الاخيرة قضاء (هيت، عنه، راوه، حديثة) على التتابع. اما نسبتها من مساحة القضاء المزروعة فتبين ان المرتبة الاولى لقضاء راوه بنسبة (74,5\%) من مساحة القضاء، وتصدر المرتبة الثانية والثالثة قضائي الرمادي والفلوجة بنسبة (64\%) و(45\%) على التتابع، وتمثلت أقضية (القائم، حديثة، هيت، عنه) بالمر اتب الاخيرة على التنابع. اما المساحات المزروعة بالذرة الصفراء بلغت (66997) دونماً ونسبتها (13,8\%) من المساحة الكلية المزروعة للمحافظة اذ تبوء المرتبة الاولى قضاء الفلوجة بنسبة (5,9\%)، ويأتي بالمرتبة الثانية والثالثة قضائي الرمادي والقائم وبنسبة (4,1\%) و (2,2\%) على التنابع، بينما تمثلت اقضية (عنه، هيت، راوه، حديثة) المراتب الاخيرة، اما نسبتها من مساحة القضاء المزروعة فتصدر قضاء راوه المرتبة الاولى بنسبة (46,1\%) من مساحة القضاء المزروعة، وتصدر قضائي القائم وحديثة المرتبتين الثانية والثالثة بنسبة (40,1\%) و(29,7\%) على التتابع، وتمثل اقضية (الرمادي، الفلوجة، هيت، عنه) المراتب الاخيرة على التتابع من مساحة القضاء المزروعة ايضاً. اما المساحات المزروعة بالشعير بلغت (35755) دونهاً ونسبتها (7,3\%) من المساحة الكلية المزروعة للمحافظة اذ تصدر قضاء الفلوجة المرتبة الاولى بنسبة (2,6\%)، ويأتي بالمرتبة الثانية والثالثة قضائي عنه والرمادي بنسبة 
(1,8\%) و(1,7\%) على التتابع، بينما تمثلت اقضية (راوه، هيت، القائم، حديثة) المراتب الاخيرة على التتابع. نسبتها من مساحة القضاء المزروعة اتى قضاء عنه المرتبة الاولى بنسبة (20,5\%) من مساحة القضاء المزروعة، وتصدر قضائي حديثة والرمادي المرتبتين الثانية والثالثة بنسبة (20,4\%) و(8,9\%) على التتابع، بينما تمثلت اقضية (هيت، القائم، راوه، الفلوجة) المراتب الاخيرة على التتابع ايضاً. وعلى الرغم من المساحات المذكورة سابقا الا ان هناك مساحات واسعة من الاراضي التي يمكن استثمارها للانتاج الزراعي اذ تظافرت الجههود المبذولة التي تهدف الى زيادة الرقعة المزروعة من خلال اعتماد خطط تنموية لتطوير الاراضي الصحراوية واستزراعها بالتوسع في استثمار المياه الجموفية والاعتهاد على تقانات الري الحديثة التي تكون ملائمة لمثل هذه المناطق، فضلاً عن مواصلة الجهود المبذولة لمعالجة كافة المشاكل وتخطي العقبات التي تواجه نجاح مثل هذه المشاريع الاستثمارية وتحول دون استغلال الاراضي بشكل جيد او العمل على زيادة مساحتها من خلال استصلاحها، ولغرض تطوير الزراعة واستغلال الاراضي الصالحة للزراعة غير المستثمرة حالياً ومدى التوسع في زر اعتها في المحافظة. وقد اوضحت الدراسة الميدانية (استمارة الاستبانة) جدول(3)، مساحات عينة الدراسة وتوزيعها على الاقضية التابعة للمحافظة، اذ اوضحت ان المساحة الكلية بلغت (2466) دونم، تصدر قضاء الرمادي المرتبة الاولى بمساحة (946) دونم وبنسبة (2.14\%)، وتصدر قضائين الفلوجة وهيت المرتبة الثانية والثالثة بمساحة (612) دونم و (300) دونم، وبنسبة (27.2\%) و(13.4\%) على التتابع، لتكون الاقضية (القائم، حديثة، عنه، راوه) ضمن المرتبة الرابعة والخامسة والسادسة والسابعة على التتابع من المساحات والنسب الظاهرة بالجدول ،مع غياب قضاء الرطبة منه لعدم توفر البيانات له . 
جدول (2): التوزيع الجغر افي والنسبي للمساحة الكلية المزروعة بالمحاصيل الاستراتيجية في منطقة الدراسة لعام 180 (دونم)

\begin{tabular}{|c|c|c|c|c|c|c|c|c|c|c|}
\hline \multicolumn{3}{|c|}{ الشعير } & \multicolumn{3}{|c|}{ الذرة الصفراء } & \multicolumn{3}{|c|}{ القمح } & \multirow{2}{*}{ المزماحة الكلية } & \multirow[b]{2}{*}{ الوحدات الادارية } \\
\hline نسبتها من مساحة & نسبتها من المساحة & المساحة المزروعة & مساحة القضاء & المساحة المزروعة & لكذاحة المزروعة المفراء & مساحة القضاء & المزروعة لمنطقة الدراسة & لمقمح (دونم) المزروعة & & \\
\hline 8.9 & 1.7 & 8450 & 21.3 & 4.1 & 20260 & 64 & 12.5 & 60898 & 95058 & الرمادي \\
\hline 4.7 & 2.6 & 12955 & 9.8 & 5.9 & 27004 & 45 & 26 & 125593 & 275093 & الفلوجة \\
\hline 7.6 & 0.4 & 2000 & 7.3 & 0.4 & 1925 & 23.2 & 1.2 & 6106 & 26254 & هيت \\
\hline 20.4 & 0.2 & 1268 & 29.7 & 0.3 & 1843 & 25.1 & 0.3 & 1557 & 6187 & حديثة \\
\hline 20.5 & 1.8 & 8950 & 6.9 & 0.6 & 3015 & 9.9 & 0.9 & 4320 & 43535 & عنه \\
\hline 5.7 & 0.05 & 248 & 46.1 & 0.4 & 2000 & 74.5 & 0.6 & 3233 & 4336 & راوه \\
\hline 7 & 0.4 & 1884 & 40.1 & 2.2 & 10950 & 37.6 & 2.1 & 10277 & 27301 & القائم \\
\hline- & - & - & - & - & - & - & - & - & 6000 & الرطبة \\
\hline- & 7.3 & 35755 & - & $13 ، 8$ & 66997 & - & $43 ، 8$ & 211984 & 483764 & الجموع \\
\hline
\end{tabular}

المصدر: وزارة الزراعة، مديرية زراعة محافظة الأنبار، قسم التخطيط، بيانات غير منشورة لعام 2018م .

جدول (3) : التوزيع المكاني والنسبي لمساحة الاراضي المزروعة التي تمتلكها الاسر الزراعية لعينة الدراسة لعام 190

\begin{tabular}{|c|c|c|c|c|c|c|c|c|}
\hline الجموع & القائم & راوه & عنه & حديثة & هيت & الفلوجة & الرمادي & القضاء \\
\hline 2246 & 229 & 29 & 25 & 105 & 300 & 612 & 946 & المساحة بالدونم \\
\hline$\% 100$ & 10.2 & 1.3 & 1.1 & 4.7 & 13.4 & 27.2 & 42.1 & النسبة المئوية \\
\hline
\end{tabular}

المصدر: بالاعتماد على استمارة الاستبانة. و الملحق رقم (3)

وتنتشر زراعة المحاصيل الاستراتيجية في جميع اقضية منطقة الدراسة لعام 180 م باستثناء قضاء الرطبة وفق بيانات عام 180 م، نتيجة الدعم الحلكومي لهذه المحاصيل، وسيتم دراسة كل ححصول وفق الاهمية والمساحة 
المزروعة وكمية الانتاج لعام 2018م، اذ تعد الحبوب من اهم المحاصيل الغذائية واوسعها انتشاراً واكثرها استخداماً سو اء للغذاء ام بشكل علف للحيوانات ام غير ذلك.

\section{ثانيًا : القتهح (WEAT):}

ينتمي القمح الى العائلة النجيلية (Gramineae Family) من نوع (Tritcum)، وله اسماء مختلفة في البلدان العربية فهو في مصر ودمشق وحوران وبقية بلاد الشام (لبنان وفلسطين والاردن) (قمح)، وفي شمالي بلاد الشام والعراق (حنطة)، وفي الجزائر واليمن (بر)، او طعام، وهو في التركية (بغدادي)، وفي الفرنسية (Ble)، وفي الانكليزية (Wheat)، وفي اللاتينية (Tritisum). والقمح من المحاصيل القديمة جداً اذ تشير المعلومات انه عرف في العراق منذ اكثر من (0007 60 ) عام قبل الميلاد، وكذلك عرف في مصر منذ (5000لقد عرف الانسان زراعة القمح قبل معرفة الكتابة، لذلك فان منطقة زراعته الاولى غير معروفة بدقة، وكان عدد من العلماء يعتقد بان القمح يعود اصله اللى ما بين بلاد الر افدين وشرق المتوسط وهضبة الحبشة، وكذلك عرف القمح في سويسرا في العصر الحجري المتأخر، كما عثر عليه برياً في بلاد الشام في جبل الشيخ وشرقي البحر الميت، كما يعتقد ان زراعة القمح بدأت في الشرق الاوسط منذ اكثر من (10000) عام، وظهرت في نهاية الالف الثانية قبل الميلاد في هذه المناطق اشكالاً ختلفة من الحياة الزراعية اعتمد اقتصادها اساساً على زراعة القمح، ولمكانة القمح الكبيرة فقد ورد ذكره في اكثر الكتب السماوية والاساطير القديمة. اما في ما يتعلق بمتطلبات القمح من الصفات المناخية، فالمناطق التي تعتمد زراعته القمح فيها على الامطار تكون متطلبات كمية الامطار ملائمة بحدود (350-1250 ) ملم(4). اما درجات الحرارة يتحمل القمح حرارة دنيا وقصوى تختلف باختلاف اطوار النمو، وتعد درجة حرارة بين (23 - 2 2مم) (5)، هي المثلى الزراعة المحصول، اما درجة الحرارة الدنيا فتتراوح بين (3-5مº) ودرجة الحرارة القصوى تتراوح بين (30-33 3م ) وبذلك فأن المحصول يحتاج الى (2330) وحدة حرارية لنموه كحرارة متجمعة(6). ومن خلال دراسة 
المقومات الطبيعية لمنطقة الدراسة نجد ملائمة الظروف المناخية لزراعة القمح، اذ ان درجة الحرارة لا تنخفض المى دون الصفر المئوي خلال فترة نمو القمح الا في بعض ايام السنة، فضلاً عن توفر فترة كافية من الجفاف اثناء عملية حصاده. اما موعد زراعة محصول القمح في منطقة الدراسة تبدأ من (15 -25 ) من شهر تشرين الثاني، اذيبدأ المزارعون بتهيئة الارض والحر اثة ومن ثم بذارها وتسميدها، ويتم حصاده خلال شهر ايار سواء بواسطة الحاصدات او يدوياً، وذلك بحسب كبر المساحة المزروعة، ويزرع القمح بأصناف مختلفة هي (آباء 99، ابو غريب، بحوث 22، رشيد، بركة، بابل) الا ان لأكثر زراعة هو نوع (إباء 99 (7). نظراً لملاعمة الظروف الطبيعية في محافظة الانبار من ظروف مناخية ووفرة مياه الري واعتحاد التقانات الحديثة التي تكون ملاءمة لزراعته ولاسيا تقانات الري بالرش المحوري والثابت التي تحتاج المى مساحات واسعة لتشغيلها كما في المناطق الصحراوية الذي اسهم في زيادة المساحة المزروعة، فضلاً عن استثلار المياه الجوفية من خلال زيادة عدد الابار المحفورة والدعم الحكومي للتوسع في زراعة المحصول ودعم اسعاره، كل هذه الامكانات جعلت محصول القمح يأتي بالمرتبة الاولى من بين محاصيل الحبوب لعام (2018م) بمساحة (211984) دونم وبنسبة (67,4\%) من مجمل لمساحات المزروعة بالحبوب الاستراتيجية، ان زراعة القمح تنتشر في جميع اقضية محافظة الانبار لعام (2018م) باستثناء قضاء الرطبة كما تم ذكره، وان اوسع انتشار للأراضي المزروعة في منطقة السهل الرسوبي، يوضح الجلدول(2) التوزيع الجغرافي والنسبي للمساحة المزروعة وكمية الانتاج لمحصول القمح في منطقة الدراسة لعام (2018م)، وتتباين المساحة المزروعة بمحصول القمح بين الأقضية اذ تبوء قضاء الفلوجة المرتبة الاولى بمساحة (125593) دونم وبنسبة (59.2\%) من بجموعة المساحات المزروعة بالقمح ومن الاسباب التي ادت الم زيادة المساحات المزروعة بالقمح في الفلوجة هي تطور وعي المزارع ما بين موسم واخر، فضلا عن تطور الآلات والمكائن المستخدمة في زراعة القمح وتطور طرق الري ولاسيا الحديثة منها طرائق الري بالرش المحوري والثابت والتي بدأت تزداد اعدادها بعد عام (2000م) مما ادى الى زيادة المساحات المزروعة بهذا المحصول كونه مادة اساسية لغذاء 
السكان، وتصدر المرتبة الثانية قضاء الرمادي بمساحة ( 60898 ) دونم وبنسبة (28.7\%) من جمموع المساحات المزروعة بالقمح، بينم) تصدر قضاء القائم المرتبة الثالثة بمساحة ( 227027 ) دونم وبنسبة (4.8\%)، بينما تمثل قضاء حديثة المرتبة الاخيرة بمساحة (1557 ) دونم وبنسبة (8.8\%) من مجموع المساحات المزروعة بالقمح اذ بلغت كمية الانتاج للمدة المذكورة (204918) طن، وتصدر قضائي الفلوجة والرمادي المرتبتين الاولى والثانية بنسبة (3 \%٪)، (30.4\%) على التتابع بكمية الانتاج والسبب في ذلك يرجع المى توفر الظروف الطبيعية الملائمة لأزدهار زراعته المتمثلة بالظروف الطبيعية والتربة الرسوبية الخصبة ووفرة مياه نهر الفرات فضلاً عن التمركز السكاني والخبرة الزراعية للمزارعين والدعم الحكومي لزراعة المحاصيل الاستراتيجية وزيادة الطلب على حبوب القمح كونها مادة غذائية اساسية للسكان، وتطور الالات والمكائن المستعملة في زراعة محصول القمح منذ بداية زراعته حتى حصاده، كل هذه الاسباب ادت المى زيادة كمية الانتاج في قضائي الفلوجة والرمادي، ويأتي قضاء القائم بالمرتبة الثالثة بنسبة (3.3 ) نتيجة لاستخدام البذور المحسنة والأسمدة بجميع انواعها ومكافحة الامراض، فضلاً عن استخدام التقانات الحديثة للري (الرش الثابت، والمحوري) التي اسهمت في تشجيع المزارعين على زراعة الاراضي الصالحة للزراعة فكانت اولى التجارب لاستخدام الري بالرش في قضاء القائم لعام (2001م) وهو ما شجع المزارعين نحو استثمار الاراضي بعد الحصول على تلك

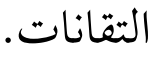

وان هذا الاستثمار هو احد اتجاهات التنمية الزراعية المستدامة في منطقة الدراسة من اجل توفير المحاصيل الاستراتيجية لسد النقص الحاصل في الطلب على كمية الحبوب المستخدمة في الغذاء اليومي للسكان (الخبز) وتحقيق الاكتفاء الذاتي من حصول القمح. اذ بلغت كمية الانتاج المسوقة في موسم الحصاد لعام (2018م) (66696.840) طن المى سايلو (خان ضاري) وسايلو (الرمادي)، كما هناك عدد من المزارعين في شعبة زراعة الكرمة قاموا بتسويق الحاصل الى سايلو التاجي بكمية بلغت اكثر (100000) طن، وتم تسويق كميات من البذور بكمية (4800) طن(8)، وقد تراوحت اسعار الطن الواحد من محصول القمح حسب الدرجة لعام ( 2018م) سعر الطن من الدرجة 
الاولى بلغ (520) الف، بينما سعر من الطن الواحد من الدرجة الثانية بلغ (480) الف ومن الدرجة الثالثة

بلغ (420) (9) (9) الف.

جدول (4): التوزيع الجغرافي و النسبي للمساحة المزروعة بمحصول القمح (دونم) وكمية الانتاج (طن) في منطقة الدراسة

\begin{tabular}{|c|c|c|c|c|}
\hline النسبة المئزية\%\% & الانتاج (طن) & النسبة المئوية\% & المساحة (دونم) & الوحدات الادارية \\
\hline 30.4 & 62368 & 28.7 & 60898 & الرمادي \\
\hline 63 & 129144 & 59.2 & 125593 & الفلوجة \\
\hline 1.5 & 3171 & 2.9 & 6106 & هيت \\
\hline 0.6 & 1156 & 0.8 & 1557 & حديثة \\
\hline 0.1 & 297 & 2 & 4320 & عنه \\
\hline 1 & 2007 & 1.6 & 3233 & راوه \\
\hline 3.3 & 6775 & 4.8 & 10277 & القائم \\
\hline$\% 100$ & 204918 & $\% 100$ & 211984 & الجمموع \\
\hline
\end{tabular}

المصدر: وزارة الزراعة، مديرية زراعة محافظة الانبار، قسم التخطيط، بيانات غير منشورة، 180 م .

اذ يتضح من خلال الجلدول(5 ) والشكل(1)، قيمة مربع كاي(10) (14 7 (14.3 7 ) اي ان هناك فرق معنوي عالي بقيمة اقل (0.01) في توزيع المساحة المزروعة بالقمح (دونم) وكمية انتاج القمح (طن)، بين الوحدات الادارية في منطقة الدراسة لعام 2018 م.

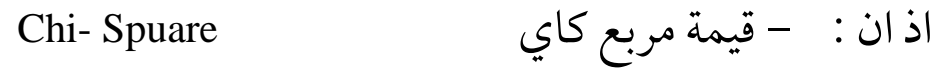

Df - درجة الخرية - 20 - 20 AsyMP- sig. مستوى الدلالة الاحصائية او مستوى الثقة - 
جدول (5): Test statistics

\begin{tabular}{|r|r|}
\hline & VAROOO1 \\
\hline Chi-square & 147.376 \\
$\mathrm{df}$ & 5 \\
AsyMP. Sig. & .000 \\
\hline
\end{tabular}

المصدر: بالاعتم)د على: 1 - الجمدول (4)، 2 -البرنامج الاحصائي SPSS

$$
\text { شكل (1) : التوزيع المكاني لمساحة القمح (دونم) بقيمة مربع كاي }
$$

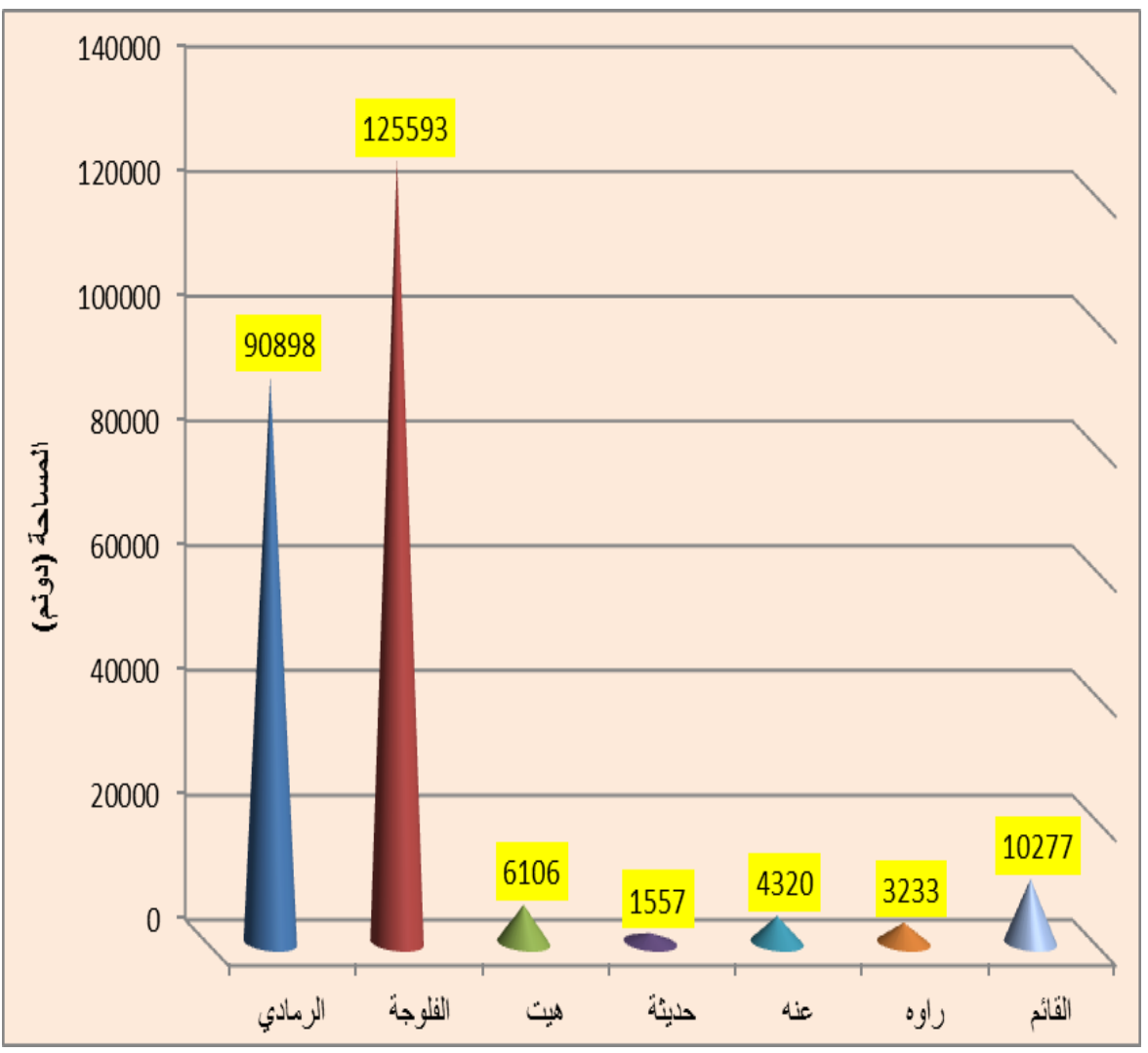

المصدر: بالاعتماد على جدول (4)

اذ يظهر من خلال الجمدول (6) والشكل (2)، قيمة مربع كاي (144.330 ) اي ان هناك فرق معنوي عالي بقيمة اقل (10 0.0 ) بين كمية انتاج القمح (طن) والمساحة المزروعة بالقمح (دونم)، بين الوحدات الادارية المختلفة في منطقة الدراسة لعام 2018م. 
ويتضح من خلال استمارة الاستبانة جدول (7) التوزيع الجغرافي لانتاجية الدونم الواحد (طن) ومعدل التسويق السنوي من محصول القمح (طن)، اذ تباينت انتاجية الدونم ومعدل التسويق بين الوحدات الادارية،

جدول (6):: Test Statistic

\begin{tabular}{|r|r|}
\hline & VAROOO1 \\
\hline Chi-square & $144.330^{9}$ \\
$\mathrm{df}$ & 5 \\
AsyMP. Sig. & .000 \\
\hline
\end{tabular}

المصدر: بالاعتماد على: 1 -الجدول (4)، 2-البرنامج الاحصائي SPSS

الشكل (2) كمية انتاج القمح (طن) بقيمة (مربع كاي)

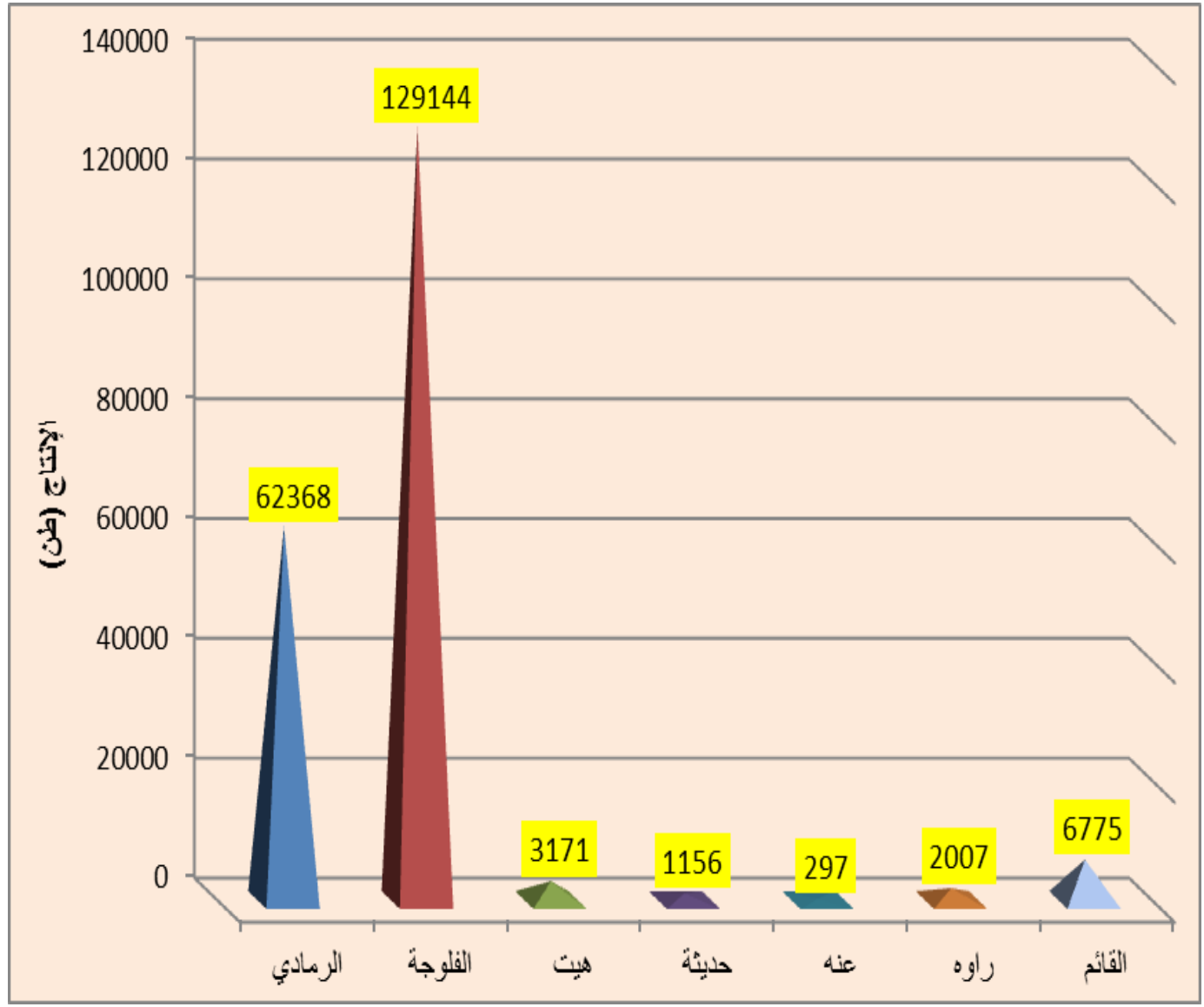

(5) - المدرر: بالاعتمادعلى جدول (5) 
اذ تصدر قضاء الرمادي المرتبة الاولى بانتاجية الدونم الواحد (25 طن) وبنسبة (48,7\%)، بينما تصدر قضاء الفلوجة المرتبة الثانية بإنتاجية (151,5 طن) للدونم الواحد وبنسبة (32,7\%)، ويأتي قضاء هيت بالمرتبة الثالثة بإنتاجية للدونم الواحد (33,6 طن) وبنسبة (\%7,2\%).

جدول (7): التوزيع الجغرافي و النسبي للإنتاجية الدونم الواحد (طن) ومعدل التسويق السنوي من محصول القمح لعينة الدراسة لعام 19 20 - ملم

\begin{tabular}{|c|c|c|c|c|}
\hline$\%$ & معدل التسويق السنوي من القمح (طن) & $\%$ & انتاجية الدونخ الواحد من القمح (طن) & الوحدات الادارية \\
\hline 32 & 337.5 & $48 ، 7$ & 225 & 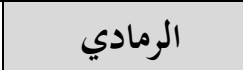 \\
\hline $34 ، 3$ & $362 ، 5$ & 32.7 & $151 ، 5$ & 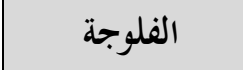 \\
\hline 8.3 & 87.500 & 6.7 & 31 & القائم \\
\hline 23 & 243 & 7,2 & $33 ، 6$ & 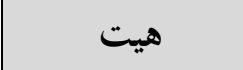 \\
\hline $1 ، 3$ & 14 & 4 & $17 ، 8$ & حديثة \\
\hline 0,5 & 5 & 0,6 & 2,7 & عنه \\
\hline 0.6 & 6 & $0 ، 1$ & 0,5 & راوه \\
\hline$\% 100$ & 1055 ،5 & $\% 100$ & $462 ، 1$ & الجموع \\
\hline
\end{tabular}

المصدر: بالاعتماد على استمارة الاستبانة.

اما معدل التسويق السنوي من القمح (طن) فقد تباينت النسب بين الاقضية، اذ تصدر المرتبة الاولى قضاء الفلوجة بمعدل (2.5 362 طن) وينسبة (34.3\%)، بينما تصدر المرتبة الثانية قضاء الرمادي بمعدل (3 33.5 طن) وبنسبة (22\%)، ويأتي قضاء هيت بالمرتبة الثالثة بمعدل (243 طن) وبنسبة (23.) وهذا مؤشر جيد نحو استثمار اراضي زراعية جديدة وزراعتها بمحصول القمح، واستخدام تقانات الري الحديثة (الرش المحوري، والثابت)، فضلاً عن رغبة المزارعين بتسويق المحصول وقلة الاستهاكك المحلي. 


\section{(Maize) (Corn) ثالثًا : الذرة الصفراء}

تعد الذرة الصفراء من محاصيل الحبوب الصيفية المهمة وهي تنتمي للاسرة النجيلية (Poaceae)، ويعتقد الكثير من الباحثين ان امريكيا الوسطى والمكسيك الموطن الاصلي للذرة الصفراء لتو اجد وانتشار انماط نختلفة من الذرة فيها، ويعتقد ان (بوليفيا وبيرو والاكو ادور في امريكا الجنوبية) المركز الثاني لها، وانتقلت الذرة الصفراء من العالم الجديد المى العالم القديم بعد اكتشافها من قبل كولمبس وبدأ يحل استخدامها محل الذرة البيضاء

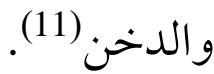

كما وتعد من المحاصيل الاستراتيجية ذات الاهمية الغذائية والصناعية في العراق، وتعد من ابرز المحاصيل الصيفية في منطقة الدراسة وتأتي بالمرتبة الثانية من حيث المساحة المزروعة بمحاصيل الحبوب بعد القمح ولها

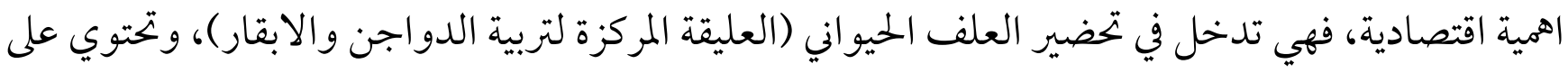
(10,2\%) من وزنه ماء و(15,2\%) مو اد زيتية و(3,8\%) مواد دهنية و(\%,9\%) مواد معدنية (كالسيوم والفسفور وحديد) وفيتامينات (B) (12)، وتكمن اهميتها في تغذية الانسان حبوب تطحن وتخلط مع القمح لصناعة الخبز

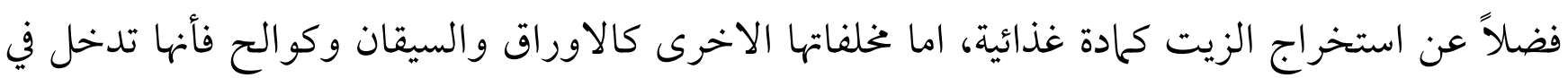
صناعة الورق(13)، وبعض المواد العازلة، ويستعمل حطبها وقود جيد لاستهلاك البيوت في الارياف، فضلا عن انها قليلة المصاريف ولا تكلف المزارع نفقات كثيرة انها لا تشغل الارض الا مدة قصيرة(14)، وتزرع الذرة الصفراء بدورتين ربيعية وخريفية، وتحرث الارض على شكل الواح مناسبة وتنثر البذور اما باليد او بآلة التسطير ثم تغطى بالترب(15)، ويفضل حراثة الارض مرتين متعاكستين وتترك لمدة (20يوم) بين الحرثينين وذلك لأبادة الادغال ولاجل وتستفاد التربة من العوامل الجوية، وتزرع بطريقتين طريقة الخطوط وطريقة المروز وهي افضل طرق زراعة الذرة الصفراء، وان كمية البذار للدونم الواحد تتراوح بين (10-12 كغم)، وتزرع بموعدين بالسنة الموعد الاول الربيعي ويبدأ من نهاية الاسبوع الاول مششهر اذار حتى اواخر الشهر لهره وتفضل الزراعة خلال هذا الشهر وعدم التأخر لان ذلك يؤدي الى قلة الحاصل نتيجة لتعرض النباتات الى لى حرارة مرتفعة في مرحلتي الازهار والاخصاب التي تسبب جفاف حبوب اللقاح وعدم الاخصاب مما يؤدي 
المى قلة الحاصل (16). اما الموعد الثاني الخريفي يكون خلال النصف الثاني من شهر حزيران و النصف الاول من شهر تموز ويمتاز هذا الموعد الزراعي بوفرة الحاصل وان تأخير الزراعة عن هذا الشهر يؤدي الى تأخر نضج الحاصل وتعرضه للامطار والتلف اخر الموسم ووقت الحصاد كما تظهر الفطريات على الحبوب لارتفاع نسبة الرطوبة في الجو فتنخفض نوعيتها ويقل سعرها(17)، وتحتاج الذرة الصفراء المى درجات حرارة عالية نوعا ما في جو لا تزيد فيه درجات الحرارة على (24 م) في النهار على ان لا تنخفض درجة الحرارة عن (14 م) في الليل (18)، وتحتاج الى اضاءة شديدة. ويتضح من الجدول (8)، التوزيع الجغر افي والنسبي للمساحة المزروعة وكمية الانتاج لمحصول الذرة الصفراء لعام 180 م، و التي انتشرت زر اعتها في جميع اقضية منطقة الدراسة باستثاء قضاء الرطبة كما تم ذكره سابقاً، وهذا مؤشر جيد في زيادة المساحة المزروعة ومن ثم زيادة في كمية الانتاج نتيجة الدعم الحكومي للعملية الزراعية في دعم التنمية الزراعية المستدامة، وتباينت المساحة المزروعة اذ بلغت (6697) دونم وبنسبة (21,3) من مجمل المساحة المزروعة بمحاصيل الحبوب الاستراتيجية، اذ تبوء قضاء الفلوجة المرتبة الاولى بمساحة (27004) دونم وبنسبة (40.3\%)، بينما تصدر قضاء الرمادي المرتبة الثانية بمساحة (20260) دونم وبنسبة (20.2 )، ويأتي قضاء القائم بالمرتبة الثالثة بمساحة ( 10950 ) دونم وبنسبة (3.36\%). اما كمية الانتاج بلغت (33497) طن، اذ تبوء قضاء الفلوجة المرتبة الاولى بكمية انتاج (17000) طن وبنسبة (50.8\%) من كمية الانتاج، بينل) تصدر المرتبة الثانية والثالثة قضائي الرمادي والقائم بكمية انتاج

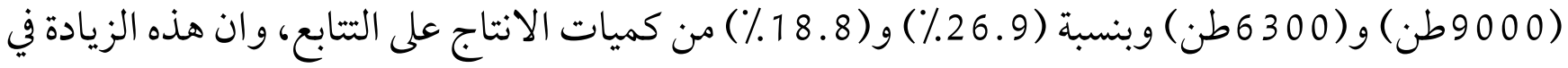
كمية الانتاج يرجع الى التطور الحاصل في العملية الزراعية وهذا عامل ايجابي نحو اتجاهات التنمية بزراعة المحاصيل الاستراتيجية، فضلاً عن استخدام الالات والمكائن الحديثة والمواد الكيميائية المخصبة من اجل رفع كمية الانتاج، وتوجه المزارعين نحو الاستثمار الزراعي في ظل الدعم الحكومي للجهات المختصة للمزارعين من خلال توفير كافة المتطلبات الزراعية التي تسهم في زيادة المساحة للعملية الزراعية من خلال دعم اسعار المحاصيل الزراعية ولاسيا محاصيل الحبوب والدعم الملإي من خلال القروض المالية وتوفير انواع الحبوب 
الجيدة ذات الانتاجية العالية، الامر الذي يتطلب الدعم المستمر من قبل المزروعة والذي ينعكس ايجابياً على الانتاج والانتاجية، والاهتمام بزراعة المحاصيل الصناعية التي تسهم في عملية التنمية الصناعية والذي ينعكس ايجابياً على اتجاهات تنمية زراعة المحاصيل الاستراتيجية واستدامتها في منطقة الدراسة.

جدول (8) : التوزيع الجغر افي والنسبي للمساحة المزروعة بمحصول الذرة الصفر اء (دونم) وكمية الانتاج في منطقة الدراسة

\begin{tabular}{|c|c|c|c|c|}
\hline النسبة المئوية & الانتاج (طن) & النسبة المئوية & المساحة (دونم) & الوحدات الادارية \\
\hline $50 ، 8$ & 17000 & 40.3 & 27004 & الفلوجة \\
\hline $26 ، 9$ & 9000 & 30.2 & 20260 & الرمادي \\
\hline 1.8 & 6000 & 2,9 & 1925 & هيت \\
\hline 1 & 335 & 2,8 & 1843 & حديثة \\
\hline 0,3 & 100 & 4.5 & 3015 & عنة \\
\hline 0.5 & 162 & 3 & 2000 & راوة \\
\hline $18 ، 8$ & 6300 & 16.3 & 10950 & القائم \\
\hline$\% 100$ & 33497 & $\% 100$ & 66997 & الجموع \\
\hline
\end{tabular}

المصدر : وزارة الزراعة، مديرية زراعة محافظة الانبار، قسم التخطيط، بيانات غير منشورة ، 2018 م

إذ يتضح من الجمدول (9) و الشكل (3 ) تظهر قيمة مربع كادي (43,100) أي أن هناك فرق معنوي عالي بقيمة أقل (010 ) في توزيع المساحة المزروعة (دونم) بالذرة الصفراء وكمية الإنتاج (طن) بين الوحدات الإدارية المختلفة في محافظة الأنبار 2018م. 
جدول (9): Test Statistics

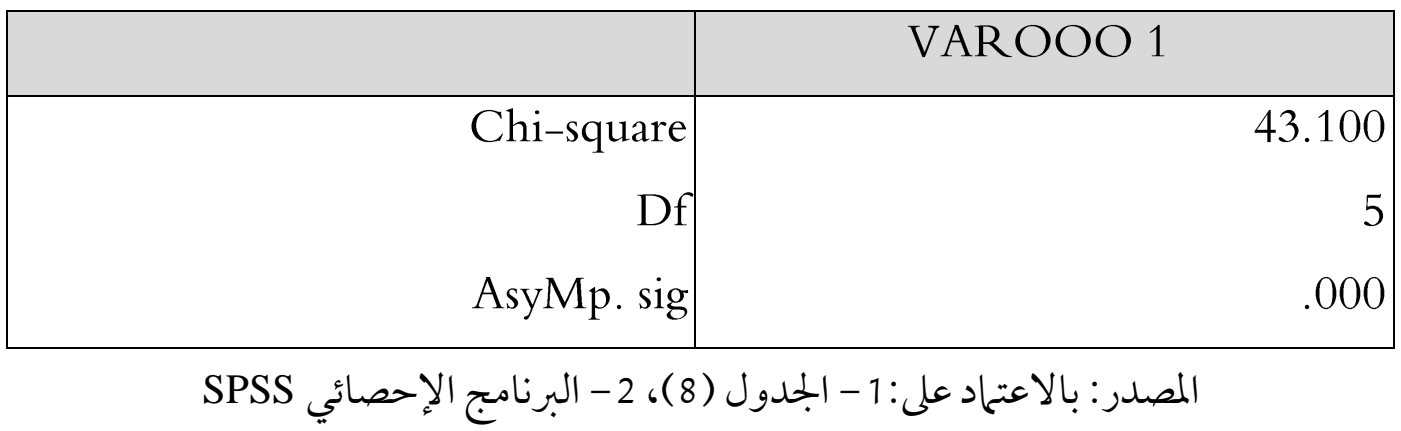

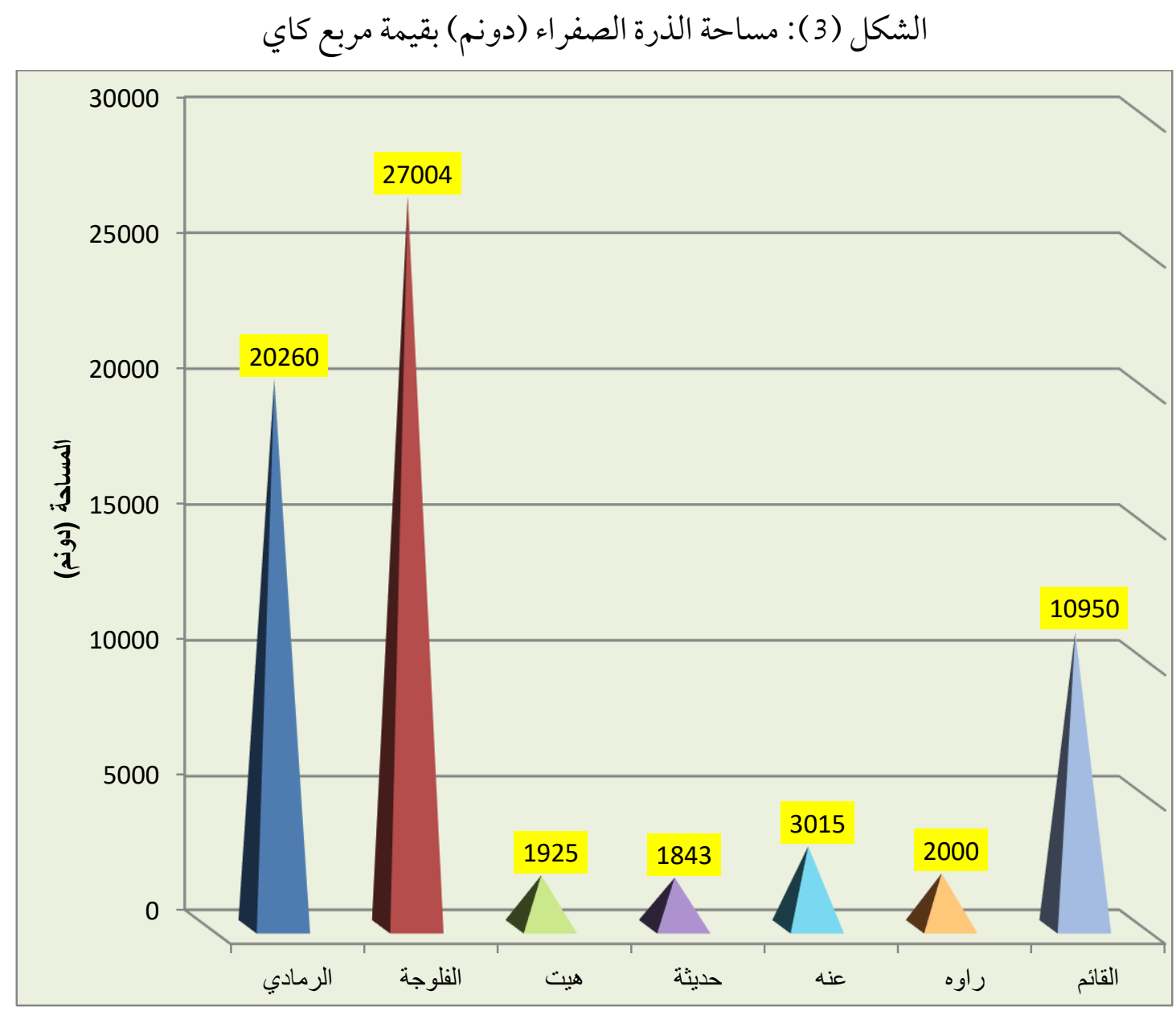

المصدر: بالاعتماد على جدول (8) 
إذ يتضح من الجدول(10 ) والشكل(4) تظهر قيمة مربع عادي (82,119) أي أن هناك فرق معنوي عالي بقيمة أقل (0,01) بين كمية الانتاج (طن) لمحصول الذرة الصفراء والمساحة المزروعة (دونم) بالمحصول بين الوحدات الإدارية المختلفة في محافظة الأنبار 2018م.

جدول (10): Test Statistics

\begin{tabular}{|r|r|}
\hline & VAROOO1 \\
\hline Chi-square & 82.119 \\
Df & 5 \\
AsyMp.sig & $000 ،$ \\
\hline
\end{tabular}

SPSS المصدر: بالاعتماد على: 1 - الجلدول (8)، 2 - البرنامج الإحصائي

الشكل (4): كمية انتاج الذرة الصفراء (طن) بقيمة مربع كاي

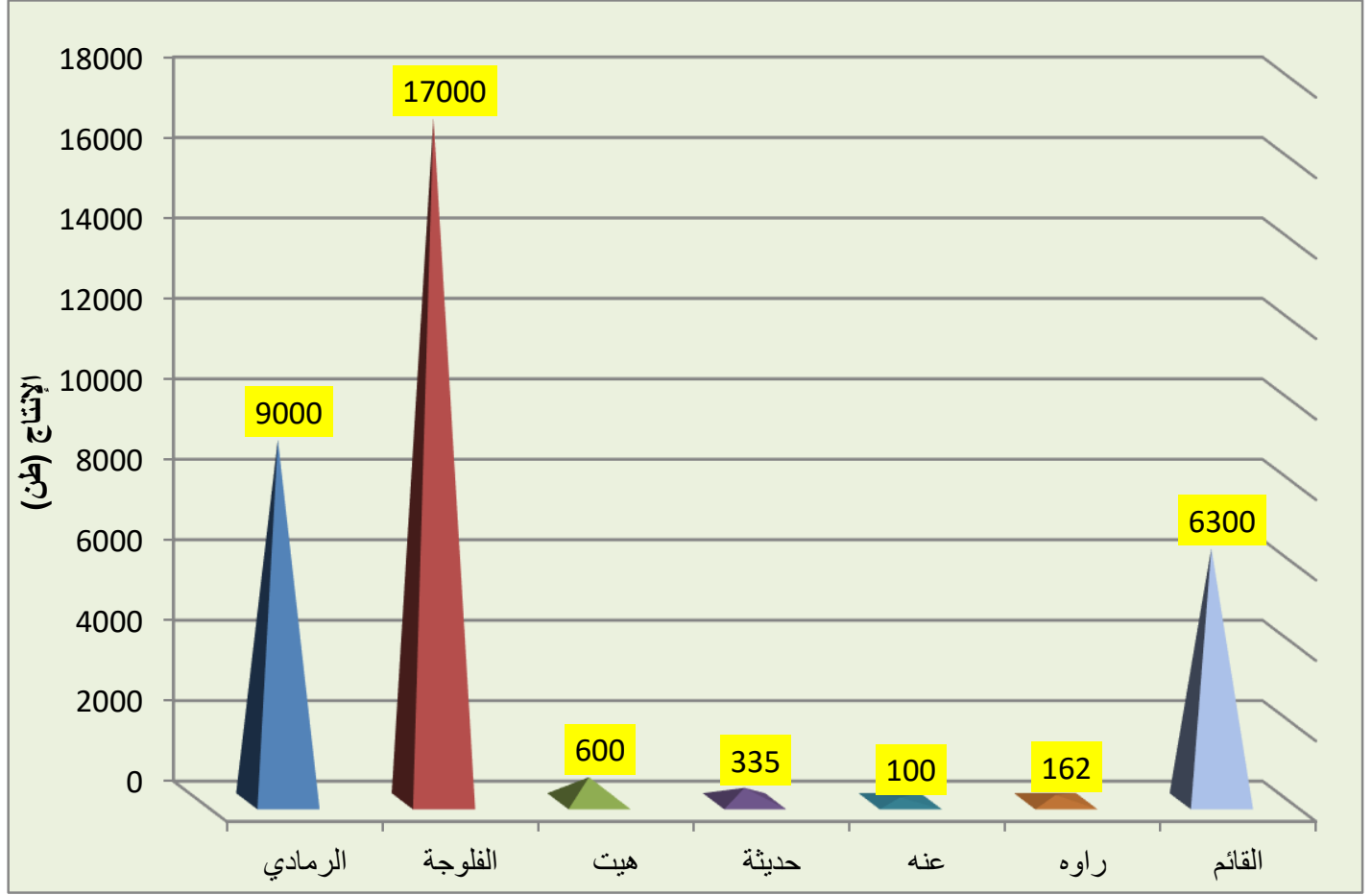

المصدر: بالاعتمادعلى جدول (8) 
ويتضح من خلال استمارة الاستبانة جدول (11 ) التوزيع الجغرافي لإنتاجية الدونم الواحد (طن) من الذرة الصفراء، إذ تباينت إنتاجية الدونم الواحد (طن) من المحصول بين الوحدات الإدارية في المحافظة، إذ تبوء قضاء الفلوجة المرتبة الأولى بكمية أنتاج بلغت (86,8) طن وينسبة (62,2\%) وهذه الزيادة في كمية الانتاج نتيجة التطور الحاصل في العمليات الزراعية من خلال أدخال الألات والمعدات، فضلاً عن استخدام الأسمدة المخصبة والمبيدات، مما أدى المى زيادة المساحات المزروعة بالمحصول، وتصدر المرتبتين الثانية والثالثة قضائي (القائم وراوه) بكمية (28) طن و(12,400) طن بنسبة (20,1\%) و(9\%) على التتابع، وهذا مؤشر جيد نحو زيادة المساحات المزروعة بالذرة الصفر اء ورغبة المزارعين بزر اعة هذا المحصول.

ويعود سبب انتشار زراعة الذرة الصفراء في العالم المى الاسباب التالية: 1 - 1 - محول مرتفع القيمة مقارنة بغيره من المحاصيل الحبوبية. 2- سهولة نقله . - 3 لان الحبوب تكون محمية من المطر والطيور بواسطة اغلفة العرنوص. 4 - سهوله حصاده وجنيه، وسهولة عزل الحبوب عن القولحة . 5- تحمله للتخزين لفترة طويلة . 67 - طول فترة حصاد المحصول ( اعتباراً قبل اكتمال نضج العرانيص الم مابعد النضج) . 
جدول (1 1 ): التوزيع الجغرافي والنسبي لإنتاج الدونم الواحد (طن) من محصول الذرة الصفراء لعينة الدراسة لعام 2019م

\begin{tabular}{|c|c|c|}
\hline $\begin{array}{c}\text { النسبة المئوية } \\
\text { \% }\end{array}$ & انتاج الدونخ الواحد (طن) من الذرة الصفراء & الإلارحدة \\
\hline $4 ، 3$ & 6 & الرمادي \\
\hline $62 ، 3$ & $86 ، 8$ & الفلوجة \\
\hline $20 ، 1$ & 28 & القائم \\
\hline 4.3 & 6 & هيت \\
\hline- & - & حديثة \\
\hline- & - & عنة \\
\hline 9 & $12 ، 400$ & راوه \\
\hline$\% 100$ & $139 ، 2$ & الخموع \\
\hline
\end{tabular}

المصدر: بالاعتحاد على استحارة الأستبانة.

\section{رابعًاً : الشعير (Barley)}

يعد الشعير نبات عشبي ومن اهم المحاصيل العلفية الشتوية التابعة للأسرة النجيلية(19)، ويسمى في بعض مجتمعات البلدان العربية (حسيكة)، وهو في التركية (آرية) وفي الفرنسية (Orge)، وفي الانكليزية (Barley)، وفي اللاتينية (Hordeum Sativum)(20)، ظهرت اقدم الدلالات على زراعة الشعير في منطقة(Jarmo) الواقعة على سفوح جبال زاجروس اذ كشفت الحفريات وجودها في هذا الموقع والتي يرجع تاريخها الى حوالي (00 70 ) عام قبل الميلاد، وكانت حبوب الشعير في هذه المنطقة مغطاة(21)، وان الموطن الاصلي للشعير قيل انه ما بين النهرين، اما العالم فافيلوف فقد افترض ان الموطن الاصلي للشعير هو الحبشة ثم قال فيمل بعد ان اسيا الصغرى هي الموطن الاصلي واثيوبيا الموطن الثاني، يعتقد ان الشعير اقدم الحبوب التي زرعها الانسان وقد تمت زراعته من قبل الامم القديمة المى عصور ما قبل التاريخ في العراق والشام ومصر وغيرها، ويظن انه نشأ

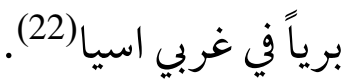


يعد الشعير رابع مصول حبي عالمي بعد القمح والارز والذرة، وزراعته من اوسع زراعات الحبوب انتشاراً ،أما في العراق يأتي محصول الشعير بعد الذرة الصفراء من بين المحاصيل الاستراتيجية في المحافظة من حيث

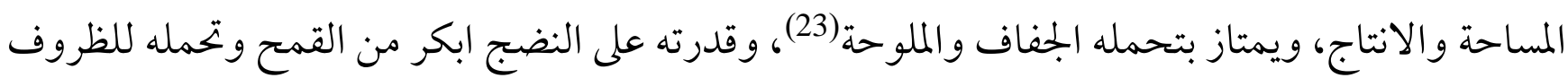

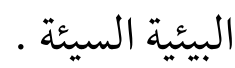

يمتاز مصول الشعير بانه اكثر تحملاً للجفاف والامراض من الحنطة، كما ان انتاجيته اعلى تحت الظروف المناخية القاسية، وتنتشر زراعته في الاراضي التي لا تجود فيها زراعة محصول القمح بسبب وجود الاملاح في تربتها، ويعد اكثر محاصيل الحبوب تحملاً لاملاح التربة في مدة الانبات والنضج، وكان لهان الشعير المصدر

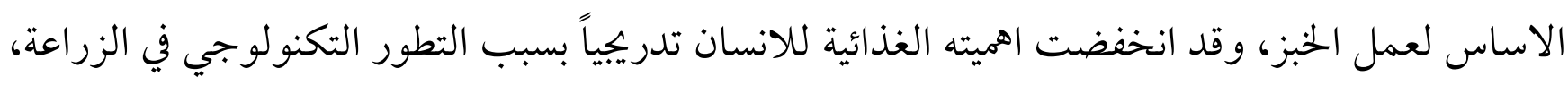
وارتفاع المستوى المعيشي، وتظهر اهمية محصول الشعير في المحافظة في استعماله علفاً للحيو انات. وتباينت المساحات المزروعة في اقضية منطقة الدراسة جدول (12)، اذ تبوء المرتبة الاولى قضاء الفلوجة بمساحة (12955 ) دونمَ وبنسبة (36,2\%) من مجموع المساحة المزروعة بالشعير، ويأتي قضاء عنه بالمرتبة الثانية بمساحة (890) دونمً وبنسبة (25\%)، بينما تصدر قضاء الرمادي المرتبة الثالثة بمساحة (8450) دونمً وبنسبة (23,6\%). اذ تعد زيادة المساحة المزروعة للمحصول هدف من اهداف التنمية الزراعية المستدامة كونه

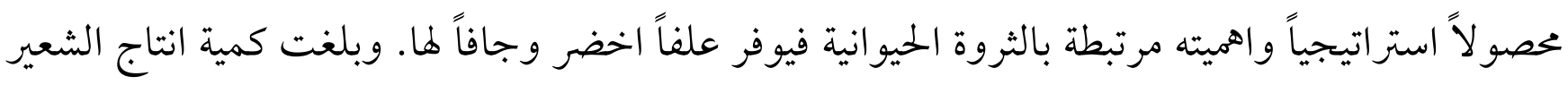

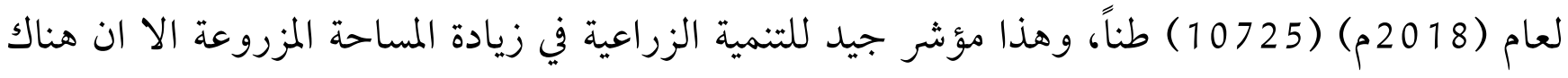
انخفاضاً في نسبة المساحة المزروعة بمحصول الشعير في عموم محافظة الانبار، اذ تصدر قضاء الفلوجة المرتبة الاولى بكمية الانتاج اذ بلغ انتاجها (592 ) طن وبنسبة (55,5\%)، ويأتي بعدها قضاء الرمادي اذ بلغت كمية الانتاج (2563) طن وبنسبة (23,9)، بينما تصدر المرتبة الثالثة قضاء هيت بكمية انتاج بلغت (1061) طن بنسبة (9.9٪) من بجمل كميات الانتاج، وهناك جملة اسباب مجتمعة اسهمت في تدهور المساحة المخصصة لزراعة الشعير المهم لتربية الماشية والابقار، فضلاً عن اهمية الغذائية كعلف للحيوانات، اذ تعادل قيمته الغذائية (15٪) من القيمة الغذائية لحبوب الذرة الصفراء(24)، واستخدامه علفاً اخضر من الاعلاف الجيدة 
للحيو انات وتستخدم سيقانه (التبن) علفاً جافاً في الشتاء، وكانت في مقدمة تلك الاسباب التوجيه الحكومي للمزارعين بضرورة تخصيص (60\%) من اراضيهم لزراعتها بمحصول القمح لسد النقص في مادة الطحين المادة الاساسية لغذاء سكان العراق والمحافظة بعد الظروف الامنية والاحداث السياسية التي اسهمت في تدني الانتاج الزراعي وتناقص المساحات المزروعة، الامر الذي يتطلب اعطاء اهميته في زيادة المساحة المزروعة بمحصول الشعير كونه محصو لاً تجود زراعته في التربة الرملية والقلوية القليلة الخصوبة التي تزيد فيها نسبة الملوحة والتي تكون رديئة الصرف كما انه يعطي حاصلاً اعلى في التربة المزيجية الجيرية العضوية ذات التفاعل(PH-6)(25)، مما يشجع على استصلاح هذه الترب وزيادة المساحة المزروعة واستثمار هذا النوع من الترب يسهم في عملية زر اعة الشعير وتنميته في المحافظة.

جدول (12 ): التوزيع الجغر افي والنسبي للمساحة المزروعة (دونم) وكمية الانتاج (طن) المحصول الشعير في منطقة الدراسة

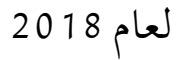

\begin{tabular}{|c|c|c|c|c|}
\hline$\%$ & الانتاج (طن) & $\%$ & المساحة (دونم) & الوحدات الادارية \\
\hline 55.5 & 5952 & 36.2 & 12955 & الفلوجة \\
\hline 23.9 & 25.63 & 23.6 & 8450 & الرمادي \\
\hline 9.9 & 1061 & 5.6 & 2000 & هيت \\
\hline 1.6 & 171 & 3.5 & 1268 & حديثة \\
\hline 2.1 & 225 & 25 & 8950 & عنه \\
\hline 1.3 & 139 & 0.7 & 248 & راوه \\
\hline 5.7 & 614 & 5.3 & 1884 & القائم \\
\hline$\% 100$ & 10725 & $\% 100$ & 35755 & الجمموع \\
\hline
\end{tabular}

المصدر: وزارة الزراعة، مديرية زراعة محافظة الانبار، قسم التخطيط، بيانات غير منشورة، 2018 م. 
اذ يظهر من خلال الجدول ( 13 ) و الشكل ( 4 ) قيمة مربع كاي (77،65) اي ان هناك فرق معنوي عالي بقيمة اقل من (0601) في توزيع المساحة المزروعة (دونم) وكمية الانتاج (طن) لمحصول الشعير، بين الوحدات الادارية المختلفة في منطقة الدراسة لعام 2018م.

جدول (13) : Test Statistics

\begin{tabular}{|r|r|}
\hline & \multicolumn{2}{|c|}{ VAROOO1 } \\
\hline Chi-square & 77.465 \\
$\mathrm{df}$ & 6 \\
AsyMP.sig. & .000 \\
\hline
\end{tabular}

SPSS المصدر: بالاعتماد على: 1 - الجلدول ( 12 )، 2 - البرنامج الاحصائي

الشكل (5): مساحة الشعير (دونم) بقيمة مربع كاي

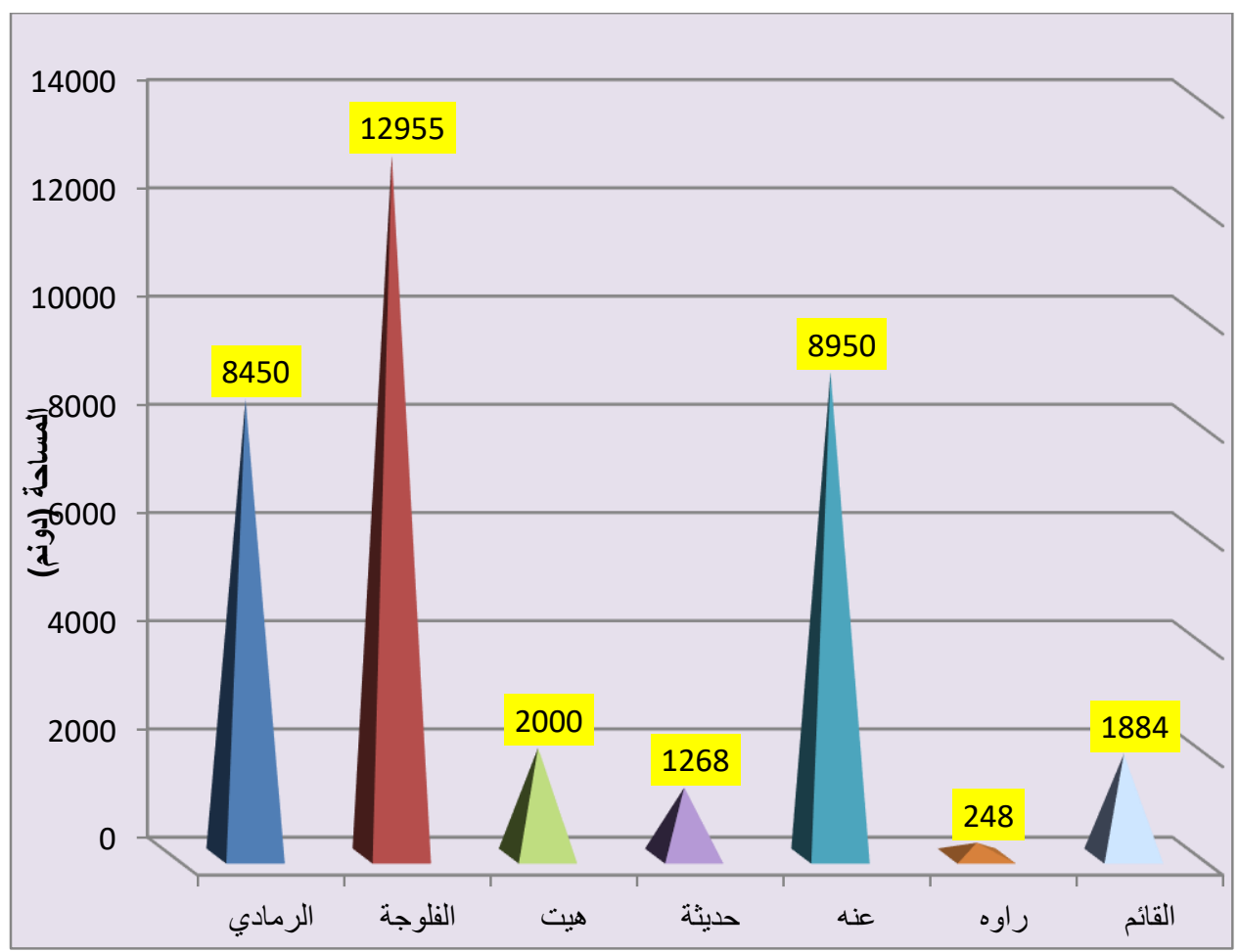

(12) المصدر: بالاعتمادعلى جدول (12) 
اذ يظهر من خلال الجمدول (14 ) والشكل (5 ) قيمة مربع كاي (128,604) اي ان هناك فرق معنوي عالي بقيمة اقل من (0,01) بين كمية الانتاج (طن) والمساحة المزروعة (دونم) بمحصول الشعير، بين الوحدات الادارية المختلفة في منطقة الدراسة لعام 2018م.

جدول (14): Test Statistics

\begin{tabular}{|r|r|}
\hline & VAROOO1 \\
\hline Chi-square & 128.604 \\
$\mathrm{df}$ & 5 \\
AsyMP.sig. & .000 \\
\hline
\end{tabular}

المصدر: بالاعتماد على: 1 - الجدول (12)، 2- البرنامج الاحصائي SPSS

الشكل (6) : كمية انتاج الشعير (طن) بقيمة مربع كاي

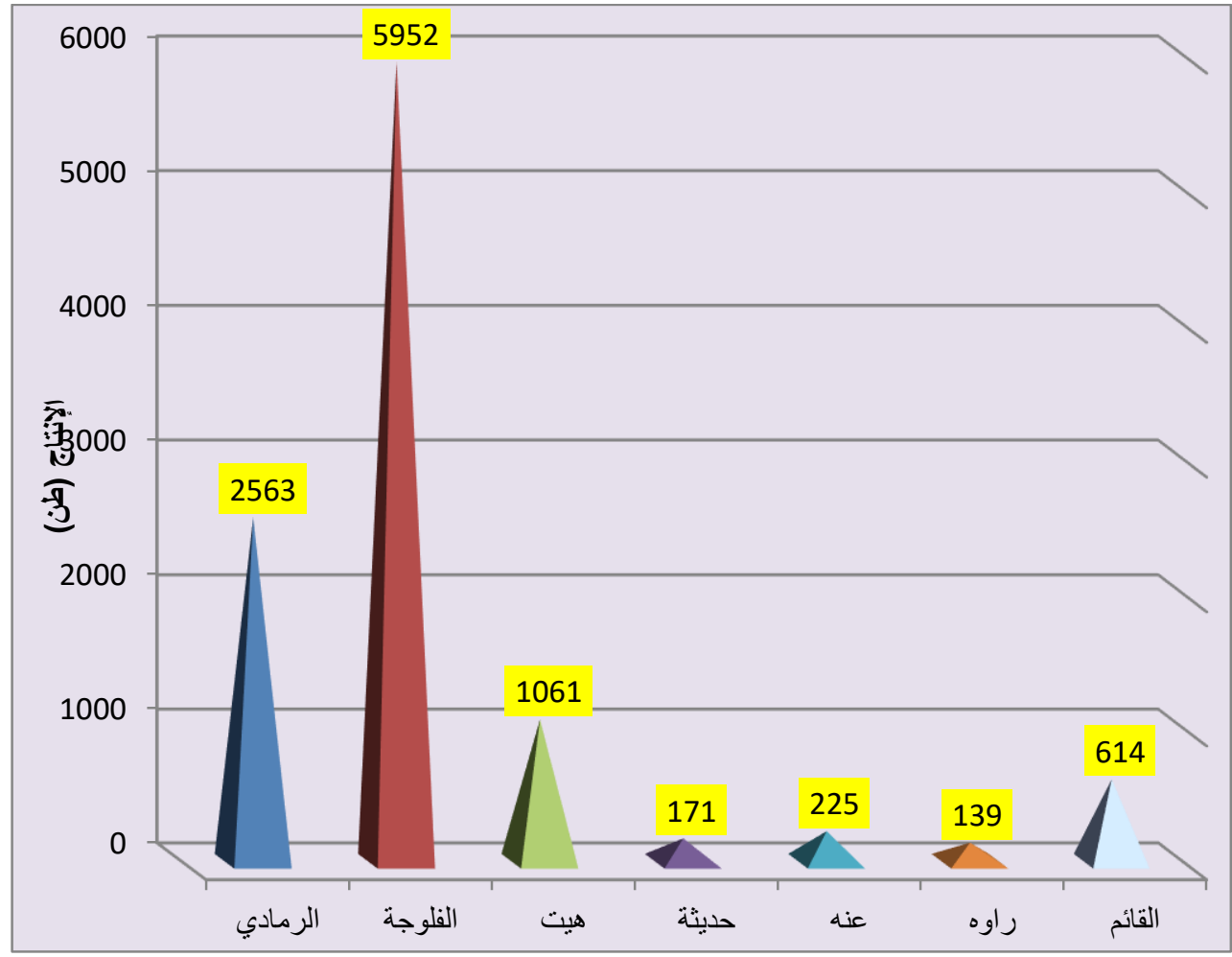

المصدر: بالاعتهادعلى جدول (12) 
ويتضح من خلال استحارة الاستبانة جدول (15) التوزيع الجغرافي والنسبي لإنتاجية الدونم الواحد (طن) من مصول الشعير، إذ تباينت إنتاجية الدونم الواحد (طن) من المحصول بين الوحدات الإدارية، إذ تصدر المرتبة الأولى قضاء الفلوجة بكمية انتاجية بلغت (68,8) طن وبنسبة (7 \%) وهذه الزيادة في كمية الإنتاج نتيجة التطور الذي حصل من خلال ادخال الآلات والمكائن في العمليات الزراعية والتي أدت المى ارتفاع المساحات المزروعة بالشعير، وتصدر المرتبة الثانية والثالثة قضائي الرمادي وهيت وبكمية إنتاجية بلغت (200) طن (20,700) طن وبنسبة (19,5\%) و(11,2\%) على التتابع، وهذا مؤشر جيد نحو زيادة المساحات المزروعة بمحصول الشعير ورغبة المزارعين بزراعة هذا المحصول لاستخدامه كعلف للحيوانات. جدول (15): التوزيع الجغر افي والنسبي لإنتاجية الدونم الواحد (طن) من محصول الشعير الدراسة في منطقة الدراسة لعام 2019

\begin{tabular}{|c|c|c|}
\hline النسبة المئوية \% & إنتاجية الدونم الواحد (طن) من الشعير & الوحدة الإدارية \\
\hline 19.5 & 36 & 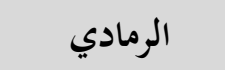 \\
\hline 47 & $86 ، 8$ & 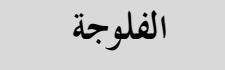 \\
\hline $10 ، 8$ & 20 & 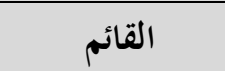 \\
\hline $11 ، 2$ & $20 ، 700$ & 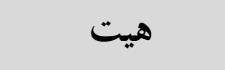 \\
\hline $10 ، 4$ & $19 ، 200$ & حديثة \\
\hline 0,3 & 0.5 & عنه \\
\hline 0.8 & 1,400 & راوه \\
\hline 100 & $184 ، 6$ & 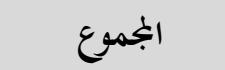 \\
\hline
\end{tabular}

المصدر: بالاعتماد على أستمارة الأستبانة. 
النتتائج:

1 - قلة مساحة الاراضي الزراعية المخصصة بزراعة المحاصيل الاستراتيجية والتي بلغت (14736 3 ) دونم على الرغم من سعة المساحة الصالحة للزراعة للمحافظة البالغة (5531559) دونم من اصل

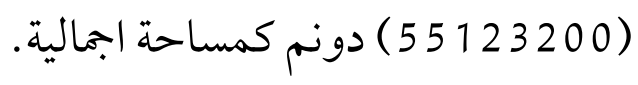

2- بلغت المساحة المخصصة لزراعة محصول القمح (21984) دونم وبنسبة (43\%) من المساحة الكلية المزروعة في المحافظة والبالغة (31476 3 3 ) دونم، و(7 6999 ) دونم، وبنسبة (13,8\%) للذرة الصفراء،

$$
\text { و(5 } 355 \text { ) دونم، وبنسبة (7,3\%) للشعير. }
$$

3- اوضحت الدراسة ان كمية الانتاج للمحاصيل الاستراتيجية بلغت (204918) طن للقمح،

$$
\text { و( } 3497 \text { ) طن للذرة الصفراء، و( } 345725 \text { ) طن للشعير. }
$$

4 - هناك تباين واضح بالقيم الاحصائية بين المساحة المزروعة وكمية الانتاج عند تطبيق مربح كاي، اذ بلغت القيمة المعيارية لمحصول القمح (147,376) للمساحة المزروعة، و(144,330) لكمية الانتاج، اما محصول الذرة الصفراء فبلغت قيمته $(43,100)$ للمساحة، و(82,119) للإنتاج، ومحصول الشعير بلغت القيمة المعيارية للمساحة المزروعة (77,465)، و (128,604) لكمية الانتاج. 5- بلغ الفرق المعنوي بين المساحة المزروعة وكمية الانتاج لجميع المحاصيل الاستراتيجية المزروعة في المحافظة الى (0,01)، مثثلاً بذلك فرقاً معنوياً كبيراً بينها. التوصيات:

1 - زيادة المساحة المزروعة بالمحاصيل الاستراتيجية باعتماد الار اضي الواعدة في منطقة الدراسة .

2 - استثمار الاراضي الزراعية بشكل اكبر من خلال تطبيق طرق الزراعة والمكننة الحديثة .

3- تشجيع الفلاحين وتثقيفهم اعلامياً وزراعياً بأهمية هذه المحاصيل وعلاقتها بالأمن الغذائي للسكان فضلاً عن اهميتها الاقتصادية . 4- تشجيع الاستثمار الاجنبي لاستغلال سعة المساحة التي تتميز بها المحافظة . 
5 - بذل الجهود للتقليل من الفرق الكبير بين كمية الانتاج والمساحة المزروعة او الصالحة للزراعة.

\section{الهوامش:}

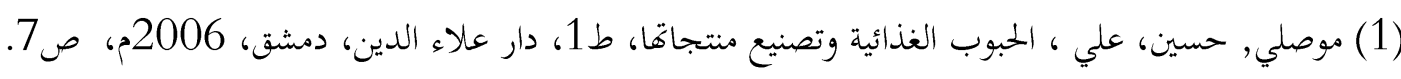

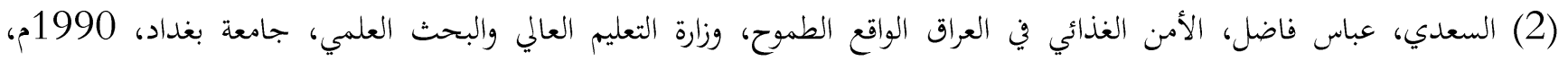

$$
\text { ص106. }
$$

السعدي, محمد عبد عيسى ، اساسيات انتاج الخحاصيل الحقلية، دار الحرية للطباعة، بغداد، 1976، ص58.

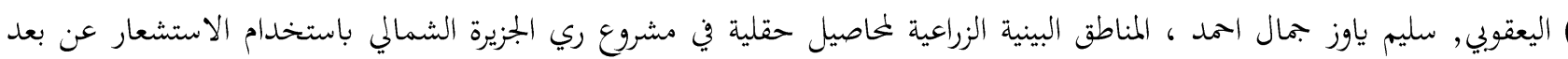

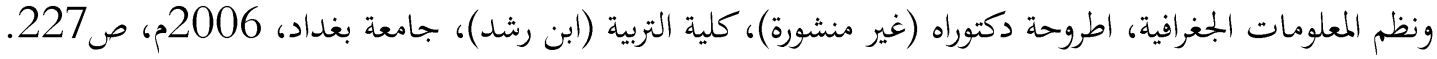

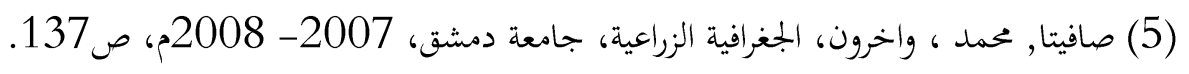

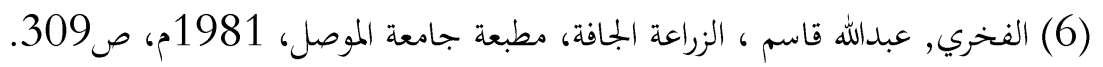

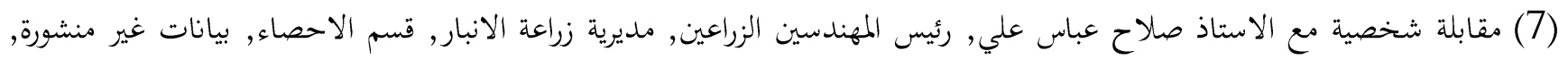

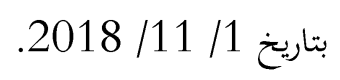

(8) التقرير السنوي للبرنامج الوطني لتنمية زراعة الحنطة في مديرية محافظة الانبار للموسم الزراعي لعام (12017- 2018م)، ص12.

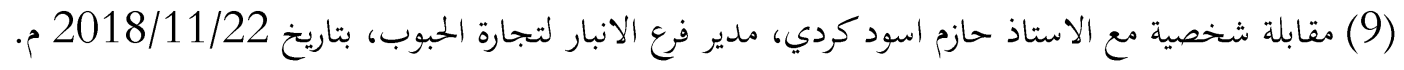

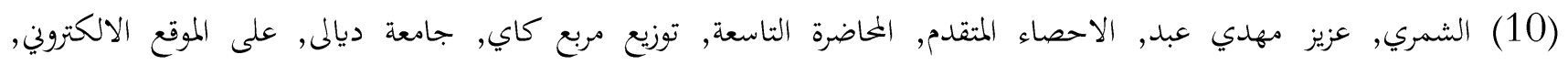

$$
\text { . 2015, Research }
$$

(11) الجنابي, محسن علي احمد, يونس عبد القادر علي, المدخل الى انتاج المخاصيل الحقلية, دار الكتب للطباعة والنشر, الموصل, جامعة

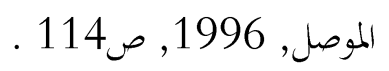

(12) ناجي, صافي ناجي، السيطرة النوعية الاحصائية لتسوق الذرة الصفراء من المحاويل الى معامل المسيب للمدة (2006-2007)، مجلة صلة

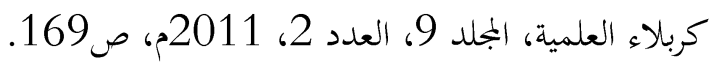

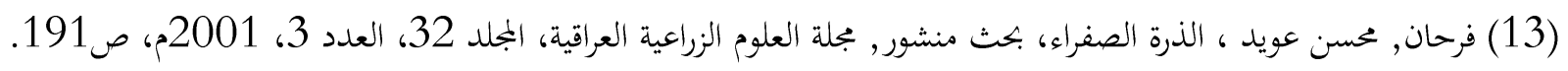

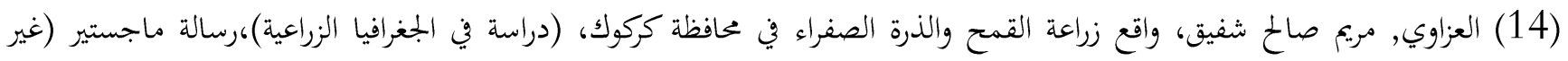

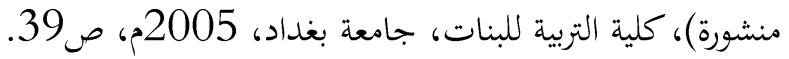

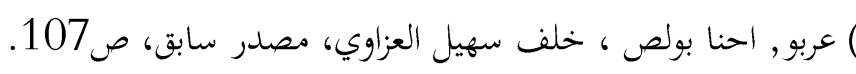

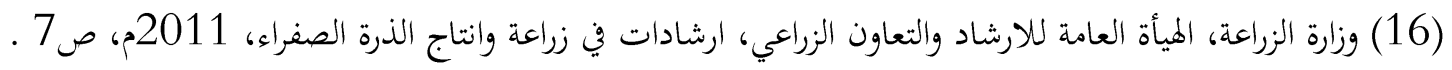

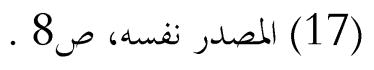


(18) احمد, شذى عبد الحسن ، مراحل وصفات نمو وحاصل تراكيب وراثية من الذرة الصفراء بتأثير موعد الزراعة، رسالة ماجستير (غير

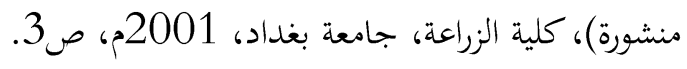

(19) البلداوي, محمد هذال كاظم، واخرون، ضوابط ومعايير زراعة ودراسة المحاصيل الحقلية، جامعة بغداد، كلية الزراعة، 2014م،

$$
\text { ص132. }
$$

(20) زكريا, وصفي, زراعة المحاصيل الحقلية, ج1, منشورات فادي برس, لندن, 2002, ص321 ص302 .

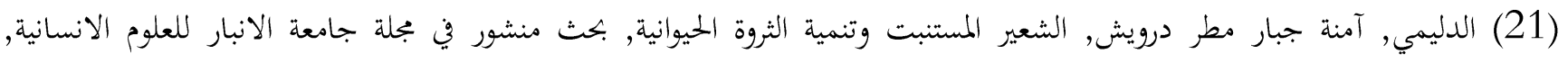

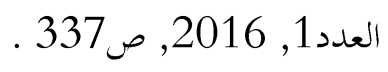

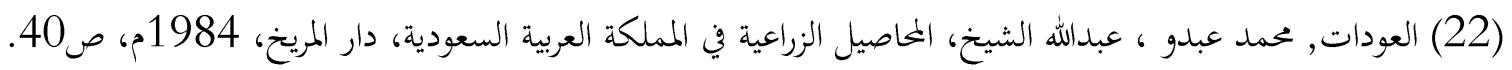

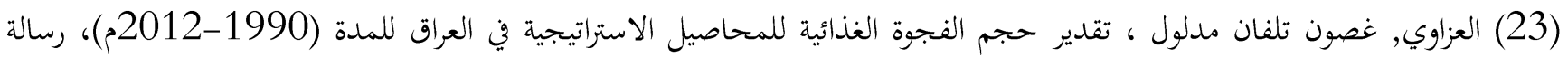

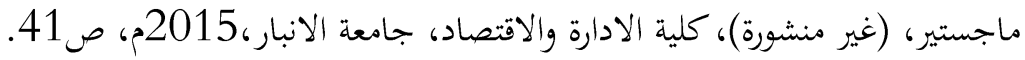

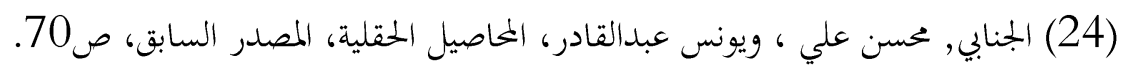

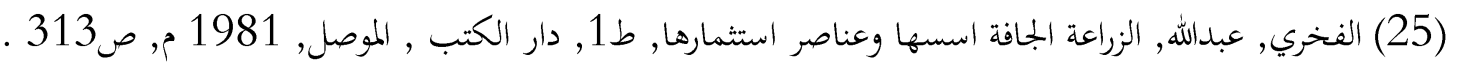

